\title{
The Walls of Fortress Europe: \\ Externalization of Migration Control and the Rule of Law
}

\author{
Angel Sí CIIEZLEGIDO
}

\begin{abstract}
1bstract: The aim of this contribution is Iwofold. First, it seeks to identify the main elements of the European policies of offshoring and outsourcing migration control and to describe the threats that these policies pose to the guarantees inherent to the Rule of Law. Second, given the serious risk of evasion of democratic controls that these policies entail, it attempts to find in the case law of European courts, specially the European Court of Iluman Rights, the elements that would make it possible to rebuild the eluded system of checks and balances.
\end{abstract}

Keyw ords: Border Control, European Migration Policy, Fortress Europe, Frontex, Access to Asy lum, Evtra-territorial Application of the ECIIR.

\section{(1) EUROPE I OFFSIIORI \GOF MIGR ITIO\CO\TROL.}

Above and beyond the lofty rhetoric used in the grand political pronouncements that have undergirded European action in the field of immigration and asylum,' it is the metaphor of Fortress Europe that best reflects the harsh reality of policies that have made border control and the fight against irregular immigration the core components of European action in this area. ${ }^{2}$ This emphasis on migration control works wo ways. In addition to a reactive dimension embodied in the return and readmission policies, aimed at forcing irregular migrants to leave, it includes a proactive facet intended to prevent such migrants

¿ Irlicle published on.31 December 2019

Professor of Public International Law, U niversity of Castilla-La Mancha (UC., M). Email: angel.slegido $a_{\text {uclm.es. This }}$ contribution is a revised and abridged version of a paper previously published in Spanish under the title "Externalización de controles migratorios versus derechos humanos" |Externalization of Vigration Control versus Ituman Rights| in 37 REEI (2019). It was written within the framework of the research projects DER2or2-35\%99, funded by the Spanish Ministry of Economy and Competitiveness, and "El Derecho Internacional y Europeo ante el fenómeno de los muros y fortalezas" |International and European Law before the Wall and Fortress Phenomenon|, funded by the government of Castilla-La Mancha. It is part of a broader studied entitled Controles migralorios y derechos humanos |Migration Control and Ituman Rights|, to be published shortly as a monograph by Tirant lo Blanch.

Since the Tampere Council Meeting, the EU has insisted that immigration and asy lum policies should be carried out "fully committed to the obligations of the Geneva Refugee Convention and other relevant human rights instruments" and be able to "ensure the integration into our societies of those third country nationals who are lawfully resident in the Union" (Tampere European Council, 15 and 16 October r999, Presidency Conclusions, para. 4). The idea of balance is also the basis for the "global" approach on which the so-called external dimension of those policies is based. See: Global approach to migration: Priorily actions focusing on 1/rica and the Vedilerranean, European Council, Brussels, ${ }_{5}$ and 16 I)ecember 2005, Annex I; European Council, Brussels, $1_{4}$ and ${ }_{5}$ December 2016 , paras. 21 and ff.; and The Global Approach to Migration and Mobility, Communication from the Commission, is November 201, COM(20n) 7 亿3 final.

2 See, per omnium, P. García Andrade, La acción exlerior de la U nión Europea en maleria migraloria. U n problema de reparlo de compelencias ( $\mathrm{V}$ alencia, 2015), at 460 and ff.

a tricle published on 31 December 2019 
from reaching European territory. Compared to the reactive dimension, this preventive facet is much more lightly regulated, is pursued much more opaquely and has received far less attention in the literature, especially in Spain.

In keeping with an approach first piloted elsewhere, and deepening a strategy initiated by the southern peripheral countries of the Schengen Area - quite singularly, Italy and Spain - the EU and its Member States have been fervently pursuing what have come to be called non-entrée $e^{3}$, non-arrival', neorefoulement ${ }^{5}$ or front-door ${ }^{6}$ policies. These policies typically entail the multiplication of so-called interception measures, in the broadest sense of the term. Interception measures refer to the set of legal, administrative and execulive actions aimed at blocking or interrupting transit to European countries, with a view to preventing access to European territory by persons who, from the time they leave the countries of origin of the main migration flows and throughout their journey, aspire to access the European Union despite not meeting legal immigration requirements. ${ }^{7}$

The proliferation of interception measures entails an externalization process, in both the geographical and functional sense. It involves not only offshoring migration control, but also entrusting it to, or, at least, involving in its performance, organizations external to and/or independent of the European Member States themselves, whether private operators, third-country agents, or supra-state agencies such as Frontex. The European Union's strategy in response to the so-called refugee crisis, outlined in the European Agenda on Migration and debuted with the controversial EU-Turkey Statement of March 2016 , unequivocally deepens these types of policies.

\section{(B) TIIE W ILLSOF FORTRESS EU ROPE: I TERCEPTION VIE ISU RES}

Within the context of the Integrated Border Management System (IBMS), interception measures at the European level are intended to target migration flows at every point of the journey. These measures are fundamentally, if not exclusively, fivefold:

(a) First, they include a two-part model for controlling access al source. On the one hand, it consists of a visa system that requires migrants from almost all countries of origin of economic migrants and

3 J. Mathaway, 'The Emerging Polities of Xon-Entrée', 91 Refugees (1992), at qo and ff.; J. Hathawav and T. GammeltoftIlansen: \on-Refoulement in a II orld of Cooperative Delerrence, University of Vichigan Law School, Law d Economics Working Papers (8 January 2014) 235-28/; A. Gerard:The Securilizalion of Vigralion and Refugee W omen (London- \ew York, 201/), at 67 and 1 f.

4 E. Tavlor Nicholson:Culting Off the Flow: Extralerrilorial Conlrols to Prevent Vigration, The Chief Justice Earl W arren Institute on Law and Social Policy, University of California, Berkeley Law School, Issue Brief (July 201 ), at 2.

5. J. IYyndman and A. Mountz, Another Brick in the Wall? Veo-Refoulement and the Externalization of Asylum by Australia and Europe', 13 Government and Opposilion (2008) 2/9-26g, at 249.

6. M. Paz, 'The Law of II alls', 28 E.JIL (2017) 6ot-62\%, al 6og.

7 Likewise, see: Inlerceplion of Asylum-Seekers and Refugees: The Inlernalional Framework and Recommendalions for a Comprehensive Approach. Execulive Committee of the Iligh Commissioner's Programme, Standing Commiltee, $18^{\text {th }}$ meeting (EC/5o SC CRP.ı7), g June 20oo, para. ı; and A. Klug and T. Itowe, The Concept of State Jurisdietion and the Applicability of the Von-refoulement Principle to Evtraterritorial Interception Measures', in B. Ryan and V. Mitsilegas: Extralerrilorial Immigralion Control: Legal Challenges (Leiden-Boston, 2010), al 69. 
refugees to the $\mathrm{EU}^{8}$ to first obtain a visa, which, except in exceptional circumstances, they must apply for at embassies and consulates abroad. ${ }^{9}$ On the other, it establishes a strict ststem of responsibility for carriers, who, under threat of harsh penalties, are compelled to perform de facto border control functions."

(b) Second, encouraging countries of origin and transil - especially neighbouring ones - lo cooperale on the conlainment of migration flows is an essential component of the IBMS and, therefore, of the external dimension of European immigration and asylum policy." The refugee crisis and the strategy embodied by the "Xew Partnership Framework" have made cooperation on migration control a central issue in EU policy vis-à-vis the main countries of origin and transit. To this end, policies aimed at securing the indispensable political will of these countries have been made stricter. They have shifted from a strategy of intrinsically and eminently positive conditionality, ${ }^{22}$ based on the granting of limited advantages with regard to migration, to one that, in addition to increasing the resources to be used, makes all EU and Member State policy towards these countries - including development cooperation policy - conditional in a way that does not rule out the use of negative incentives as well.'”

8 Introduced in 1993 in the context of Schengen, the common list was incorporated into EU law in 2001, after the necessary attribution of powers by the Treaty of Amsterdam to the then European Community. See: Council Regulation (EC) Vo 539200 of $y_{5}$ March 200 listing the third countries whose nationals must be in possession of visas when crossing the external borders and those whose nationals are exempt from that requirement (OJ L 8I, 2 I March 2001, at I). As it has been amended more than $y_{5}$ times, it is advisable to check the unofficial codified version: Doc. 02001 Ro539-201706m.

9 See, in relation to the uniform visa, Articles f.r and to of the Community Code on Visas. Regulation (EC) Vo $810 / 2009$

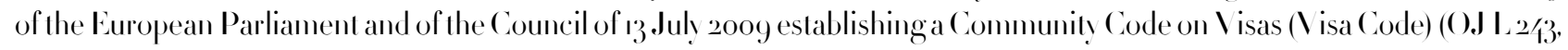
${ }_{5}$ September $\left.2009,1-58\right)$.

10 Council Directive $2001 / 5^{1}$ EC of 28 June 2001 supplementing the provisions of Article 26 of the Convention

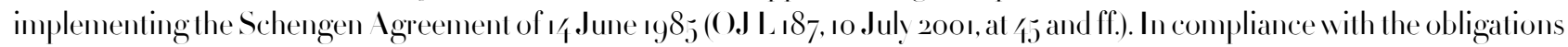
so undertaken, in Spain, the inbound control system implemented by carrier companies is regulated under Art. 66.3 of the Law on Immigration (LOEX), and Arts. I6 and 8 of its implementing regulations (REX). On the access control system based on the establishment of a system of responsibility on the part of carriers, see: V. Moreno-Lax, 'Must EU Borders Ilave Doors for Refugees? On the Compatibility of V isas and Carrier Sanctions with Member States' Obligations to Provide International Protection to Refugees', European .Journal of IVigration and Law (2008), at 355 and ff.; T. Rodenhäuser, 'Another brick in the wall: carrier sanctions and the privatization of immigration control', 26 I.JRL (2014) 223-2亿7.

" S. Gil Araujo, 'Redefiniendo las fronteras de Europa. Sobre la deslocalización del control migratorio comunitario’, in I. Markez (ed.): Respueslas a la exclusión. Polílicas de inmigración, inlerculturalidad y mediación (Donostia-San Sebastián, $2006)$, at 60 .

12 On the traditional reservations regarding negative conditionality, in particular, as a response to the Spanish-British proposal submitted by the Blair and Aznar governments at the Seville Council Meeling in 2002, see: K. Eisele, EU Evernal Relations and Migration Policy: The I Iistorical Development of the External Dimension', in J. Viessen and E. Guild (eds.): The Exlernal Dimension of EU Immigralion Policy (Leiden, 201/), at 99 and ff.; and S. Lavenex, 'Shifting $\mathbf{P}$ and Out: The Foreign Policy of European Immigration Control', in V. Guiraudon and G. Lahav (eds.): Immigration Policy in Europe: The Politics of Conirol (London, 2007), at 329 and fi.

3 Communication from the Commission to the European Parliament, the European Council, the Council and the European Investment Bank on establishing a new Partnership Framework with third countries under the European Agenda on Migration, Brussels, 7 June 2016, COM(2016) $3^{8} 5$ final, at so. On the new approach embodied by this strong emphasis on negative incentives and the ensuing controversy, see: C. Castillejo, The EU Migration Partnership Framework: Time for a Relhink?', German Ievelopment Instilule, Discussion Paper 28 2017. 
Achieving and maintaining political will is not enough. It is also necessary to build up the capacily of these third countries, providing them with material resources, training their personnel and using the appropriate technological means to ensure effective surveillance and the exchange of information required to successfully carry out the interception operations. Largely replicating the networked cooperation structure that the Spanish ${ }^{1 / 1}$ and Italian ${ }^{15}$ border control services have used over the past decade with their respective African partners, the European Union has, via Frontex, assumed the mission of promoting and deepening this operational cooperation, involving as many Member States as possible in the effort. ${ }^{\prime 6}$ As a result, outbound migration control actions involve a wide variety of players, including, in addition to third-country border control services, supra-state agencies (Frontex), peripheral EU Members States, and other Member States providing support for these peripheral states. Whilst these limits do not fall within the scope of primary law, Frontex Regulation nevertheless limits the powers of this European border agency, which, despite its name, has no border guards.'7 This, coupled with the added value that the peripheral Member States can bring to these operations, explains why, whenever possible, this operational cooperation relies on those states for leadership. In any case, the extraordinary opacity surrounding this operational cooperation, whether it is carried out directly by Frontex or implemented by the Member States, makes it extremely difficult to learn the details of the specific types of cooperation involved in the performance of material interception operations.

(c) Building on the precedent of similar practices carried out in the United States and Australia, ${ }^{8}$ the EU Member States have begun to conduct various ly pes of sea patrol operations that include interception

ı. L. Gabrielli, 'La externalización europea del control migratorio dLa acción española como modelo?', Anuario CII)OB de la Inmigración 20r7, at 129 and ff.; and V. Casas Cortes el al., "Good neighbours make good fences": Seahorse operations, border externalization and extra-territoriality', 23 European $($ rban and Regional Studies (2016), al 231 and ff.

i.5 A. I)i Pascale, 'Migration Control at Sea: The Italian Case', in B. Ryan and X. Mitsilegas (eds.): Extralerrilorial..., supra n. 7, at 296 and If.; and S. I aamood, 'EU - Libya Cooperation on Migration: A Raw Deal for Refugees and Migrants?', 21 Journal of Refugee Studies (2008), 19-12.

16. Cooperation with third countries, "focusing in particular on neighbouring countries and on those third countries which have been identified through risk analy sis as being countries of origin and/or transit for illegal immigration" (Art. 4.f) is one component of European integrated border management. It has been defined as an objective of the European Border and Coast Guard with a view to managing i.e. controlling border crossings and addressing the challenges of migration and crossborder crime (Art. 价. See: Regulation (EU) 2016/162/4 of the European Parliament and of the Council of I/4 September 2016 on the European Border and Coast Guard (O.J L 2 2 I, I6 September 20I6, at I and ff.) (hereinafter, Frontex Regulation).

${ }_{7}$ See Art. 2, para. 1/, of the Schengen Borders Code (Regulation 2016 399), cited in Art. 2.3 of the Frontex Regulation, as well as Art. 20 of this latter instrument.

18 On U S practice, see: \. Frenzen, 'U S Migrant Interdiction Practices in International and Territorial Waters', in B. Ruan and V. Mitsilegas (eds.), Extralerrilorial..., supra n. 7, at 375 and ff.; \. Legomshy, The US I and the Caribbean Interdiction

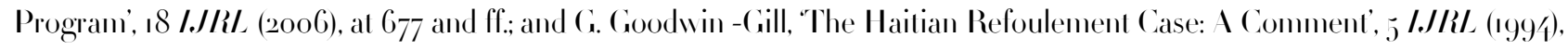
103-110. On Australian practice, including the famous Tampa case, see, amongst others: C. Bailliet, The Tampa Case and Its Impact on Burden Sharing at Sea', 2ృ IIuman Righls Quarlerly (2003), al 7亿1 and ff.; C. M.J. Bostock, The International Legal Obligations Owed to the Asylum Seekers on the W/T Tampa, I.JRL (2002), at 279 and ff.; S. Kneebone, 'Controlling Vigration by Sea: The Australian Case, in B. Ryan and V. Mitsilegas (eds.): Extraterritorial..., supra n. 7, at 347 and ff.; P. Mathew, 'Australian Refugee Protection in the $W$ ake of the Tampa', 96 A.JIL (2002), al 66r and ff.; and E. Willheim, 'MIV Tampa: The Australian Response', ${ }_{5}$ I.JRL (2003), at $1_{59}$ and lf. 
measures. In the Italian case, in accordance with agreements with the Albanian and Libyan authorities, Italian patrol boats directly detained and returned intercepted migrants to the coasts of departure. The ECIIIR's rejection, in 2013, of this policy of returning migrants to Libya prompted a change of strategy, consisting in building up the Libyan coastguard's material, logistic and personal capacity and charging it with carrying out this practice directly. ${ }^{19}$ Subtler from the outset, the Spanish operations, conducted in third-country waters in the form of joint patrols - in practice, agents from those countries are brought onboard Spanish patrol boats - avoid contact with migrants through interceptions based on the interposition and action, in the form of directions, of local agents. ${ }^{20}$

The creation of Frontex has, through its most visible and costly activity, strengthened national actions with major operations. With European funding, the Agency organizes and coordinates the support of Member States, and any third countries that voluntarily agree to it, for the Member State that is especially affected, which, in turn, leads the operation. Maritime operations are subject to detailed regulations, enshrined in the 201/4 Sea Borders Regulation, ${ }^{2}$ derived from the general concept governing the Schengen and Dublin systems, whereby the host state is responsible for the operation's operational management and the disembarkation of the intercepted persons. Despite the progressive inclusion of search and rescue activities in the mandate of the maritime operations, they are an incidental and secondary function in relation to their main mission, which is none other than border control. In any case, the operations are carried out with a remarkable opacity and lack of transparency. ${ }^{22}$

(d) Although they have received far less attention in the media than similar infrastructure in other countries, the peripheral Member States whose land borders are most affected by irregular migration flows have been making a serious effort to secure those borders through the construction of so-called migration fences. In fact, these are more or less sophisticated structures that usually combine deterrent

19. Regarding Italian practice prior to Colonel Qaddafï's fall, see: S. Ilamood, 'EU-Libya Cooperation..., supra n. 15 , at ig and ff.; A. I)i Pascale, 'Migration Control..., supra n. ${ }_{5}$, al 296 and ff.; and E. Papastavridis, The Inlerceplion of I essels on the IIigh Seas: Contemporary Challenges to the Legal Order of the Oceans (O)ford, 201/), at 28/4 and ff.

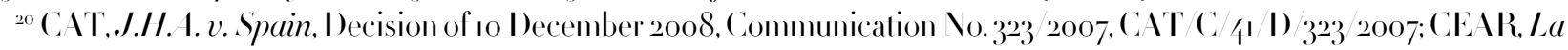
siluación de los refugiados en España. Informe 2008, at $5^{1}$ and ff.; and A. Sánchez Legido:Controles migralorios y derechos humanos, section 2.3 .2 (fortheoming).

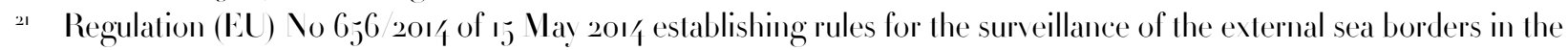
context of operational cooperation coordinated by the European Ageney for the Management of Operational Cooperation at the External Borders of the Member States of the European L nion (OJ L 189, 27 June 201/4, 93-107).

${ }_{22}$ For an overview of Frontex's maritime operations, see: J. I. Quindimil López, 'La Unión Europea, Frontex y la Seguridad en las Fronteras Marílimas. ¿Hacia un Modelo Europeo de Seguridad Ilumanizada en el Mar?', q Revisla de Derecho Comunilario Europeo (2012), at .57 and ff.; G. I. Oanta, 'Desarrollos jurídicos controvertidos en la vigilancia de las fronteras marítimas exteriores de la Unión Europea en el marco de Frontex. A propósito de la Decisión $2010 / 2 \jmath^{2}$ U E’, in J. M. Sobrino Ileredia el al. (eds.): El desarrollo del Tralado de Lisboa: un balance de la Presidencia española. Décimas Jornadas Extraordinarias Escuela Diplomálica-Asociación Española de Profesores de Derecho Inlernacional y Relaciones Internacionales, Madrid, 22 June 2010, Escuela Diplomática, Ministerio de Asuntos Exteriores y de Cooperación, Colección Escuela Diplomática \o. 17 (2011), at ı7ı and ff.; F. Esteve García, El rescate como nueva función europea en la vigilancia del Mediteráneo', m Revista CII)OB d' Ifers Inlernacionals (2015), at 153 and ff.; and S. Marinai, 'The interception and rescue at sea of asylum seekers in the light of the new EU legal framework, „aj Revisla de Derecho Comunilario Europeo(2016), at gor and lf. 
and containment features - fences, barbed wire, ditches or pits - with communication channels and technological surveillance and detection devices. W ith the conspicuous precedent of the sophisticated Ceuta and Melilla fences, ${ }^{23}$ built in the late 1990 and substantially reinforeed since then, at least half a dozen other EU Member States - including Greece, Bulgaria, Mungary, Slovenia, Austria and France - in addition to one neighbouring country - Macedonia - have decisively undertaken more or lesssimilar initiatives. ${ }^{21}$ Although, given the unpopularity of these types of migration control mechanisms, the European Commission has traditionally distanced itself from any express support for them, the model on which the Schengen system is based clearly encourages the peripheral Member States to use them.

(e) Finally, European countries have also resorted to the excision of lerrilory, i.e. partially stripping border areas of their status as state territory in order to deny those who reach them the guarantees arising under migration and asylum law. This would include the French and British practices with regard to the international areas of ports and airports ${ }^{25}$ or the imaginative concept of operational border developed by Spanish Interior Ministry authorities. ${ }^{26}$ I lowever, this procedure has not yet taken on the importance it has acquired elsewhere, especially in Australian practice. ${ }^{27}$ This is largely due, as will be seen below, to the ECIIIR's case law.

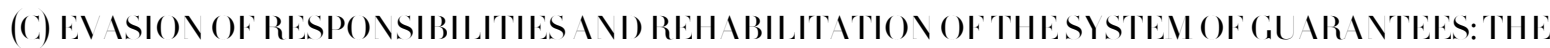
RESPO\SEOF THEEU ROPE II COU RT OF IIU MII RIGITS

To attempt a legal analysis of these European externalization policies, it is first necessary to recall four ideas. First, the implementation of these policies can have horrible consequences for the people subjected to the interception measures, both in material terms and for the enjoyment of human rights. Second, although states have wide-ranging recognized sovereign powers to regulate the entry and stav of aliens in

${ }_{23}$ J. Castán Pinos, 'Building Fortress Europe? Schengen and the Cases of Ceuta and Melilla', Morking Paper, Centre for International Border Research, Belfast, 20og; M. A. Acosta Sánchez, 'Las fronteras terrestres de España en Melilla: delimitación, vallas fronterizas y lierra de nadie', 28 REEI (201/), at 17 and ff.; and S. Saddiki: II orld of II alls: The Struclure, Roles and Effectiveness of Separalion Barriers (Cambridge, 2017), at 57 and lf.

24 A. Sánchez Legido, Controles migralorios..., supra n. 20, section 2.1.

${ }_{25}$ See, respectively, the factual background of the Amuur and Gebremedhin cases cited below and R. Barnes, The International Law of the Sea and Migration Control', in B. Ryan and V. Mitsilegas: Extraterrilorial..., supra n. 7, at II7-ı9. For an overview of these types of practices, see: A. Valle Gálvez, 'Las zonas internacionales o zonas de tránsito de los aeropuertos, ficción liminar fronteriza', 9 REEI (2005), at 3 .

26 It is a paralegal reasoning tactic developed by the Interior Ministry, intended to provide a legal basis for so-called hol relurns, whose trail must be traced through the parliamentary remarks and statements of Interior Ministry officials and internal documents of the Civil Guard commanders. For more information, see: P. García Andrade, 'Devoluciones en caliente de ciudadanos extranjeros a Marruecos', 67 REI)I (2015-1), at 21/4 and ff.; and I. González García, 'Inmigración y derechos humanos: las devoluciones en caliente de inmigrantes subsaharianos desde España a Marruecos', i7 Anuario de los Cursos de Derecho Ilumanos de Donostia-San Sebastián (2017), at $1_{5}$ and lf.

${ }_{27}$ Undoubtedly, the most conspicuous example is that of the immigration detention and processing centre built by the Australian authorities on Christmas Island. See: Commonwealth Ombudsman, Christmas Island immigration delention facilities. Report on the Commonwealth and Immigralion Ombudsman's Oversight of Immigralion Processes on Christmas Island. Oclober 2008 to Seplember 2010 . February 201 . 
their territory and to enforce those regulations, those powers are not unlimited. Amongst the limits, those arising under international and European human rights law and law on international protection are preeminent. ${ }^{28}$ Third, at least in the case of Europe, the countries that implement and the institutions that promote the externalization of migration control are defined, respectively, as states and as a union based on the rule of law. As the Luxembourg court recalled in the Les Verts.2y case, this means that all public power is subject to the law. And, fourth, notwithstanding all these considerations, more than a few authoritative voices have suggested that the migration control externalization policies conceal a strategy for evading responsibilities and circumsenting domestic and international legal guarantees through a dissociation of controls and rights that displaces the former without accompanying them with the latter. $3^{30}$

V. Mitsilegas is right when he notes that such policies pose intense challenges to the requirements arising under the rule of law and to the core of the notion of human dignity. 3' Surely, as suggested by B. Ryan, the best way to tackle these challenges is to try to restore the legal and democratic guarantees that have thus been excluded..$^{32}$ In such a restoration of the eluded controls, the response of the international bodies tasked with safeguarding human rights, in particular, the ECIIIR, is extraordinarily important. In fact, in response to the question of whether or not those controls can be restored, the Strasbourg court's case law offers some affirmative answers, which, although only partial with regard to the general panorama of offshoring policies, are nevertheless important.

Thus, the Court has rejected the fic titious offshoring strategies embodied by the excision of areas and territories in relation to the international areas of ports and airports since the early Amuur v. France ${ }^{33}$ case. In contrast, under the pretext of not getting into the Spanish-Moroccan territorial dispute over areas in Vorth Africa, the chamber that decided the N.T. and N.I. v. Spain case in the first instance sidestepped the issue of whether the land between the Melilla fences is territory subject to the Convention's

28 For an overview of this issue, see the recent contribution: S. Torrecuadrada García-Lozano, 'Los derechos humanos como límite a la gestión de los flujos migratorios mixtos', 36 REEI (2018).

29 ECJ Judgment, Parti écologiste “Les V erts” v. European Parliament, C-294 83, EU:C:1986:166, para. 23.

$3^{\circ}$ In this regard, see, amongst others: L. Bialasiewicz, "Off-shoring and out-sourcing the borders of Europe: Libya and EU border work in the Mediterranean', i7 Geopolitics (2012), at 8/3 and ff.; T. Gammeltoft-IIansen, The refugee, the sovereign and the sea: EU interdiction policies in the Mediterranean', IIIS Working Paper, No. 2008 6, at 258; B. Rvan, Extraterritorial Immigration Control: What Role for Legal Guarantees?', in B. Rvan and V. Mitsilegas: Extralerrilorial..., supra n. 7, at 3 ; E. Brower, 'Extraterritorial Migration Control and Ituman Rights: Preserving the Responsibility of the EU and Its Member States', in B. Ruan and V. Mitsilegas, Extralerrilorial..., supra n. 7, at 2oo; E. Tavlor Vicholson, 'Culling off the Flow: Extraterritorial Controls to Prevent Migration', W arren Institute, University of California, Berkeley Law School, Julv 2011, at 2; M. Fernández, La responsabililé du fail des violations des droils de l'homme dans le cadre des opéralions marilimes coordonnées par l' Igence Fronlex, Université Panthéon- Assas, Paris, 2012, at 6;; and M. Paz, 'Between the Kingdom and the Desert Sun: I Iuman Rights, Immigration, and Border W alls', 34 Berkelev Journal of Inlernalional Law (2016), at 21.

${ }^{31} \quad$ V. Mitsilegas, 'Extraterritorial Immigration Control in the $21^{\text {st }}$ Century: The Individual and the State Transformed', in B. Ryan and V. Mitsilegas: Extralerrilorial..., supra n. 7, at $6_{3}$.

$3^{2}$ B. Ruan, Extraterritorial..., supra n. 7 , at 46 and ff.

33 Amuurv. France, $2_{5}$ June $1996, \$ 39$, Reports 1996 -III, $\$$ \$ 4 and ff. The same idea underlies the decisions of the ECtIIR in the cases I). v. The I niled Kingdom, 2 Mav 1997, Reports 1997-III, $\$$,8, and Gebremedhin /Gaberamadhien/v. France, No. 25389 o5, 26 April 2007, $\$ \$ 66-67$, Reports 2007-II. The Spanish Constitutional Court's position is likewise based on it. See: Constitutional Court M rit 5.5996 , of 6 March, F.J. 
application. ${ }^{3 i}$ I Iad it adopted a different attitude and based jurisdiction on the territorial link, it would have confirmed that the migration fences were fully subject to the limits that the Convention imposes on such facilities, as the ECAIIR itself already noted in its judgments on the Berlin Wall.35 This appraisal is hardly trivial, given the concerns raised by certain recurring features in the design of anti-migration fences. ${ }^{36}$ Spain's appeal of the decision offers the Gand Chamber the chance to rectify this mistake.

Likewise, in an allitude diametrically opposed to that taken by the US ${ }^{37}$ and Australian ${ }^{38}$ Supreme Courts, in the pivotal IIrsi. Jamaa case, the ECIIIR confirmed the Convention's applicability to maritime interceptions carried out by agents of the States Parties on the high seas from state vessels flying their flags. ${ }^{39}$ It further found that the removal of intereepted or rescued persons to the authorities of a third country where there exists a real risk that they will be subjected to inhumane treatment, with no prior identification and without affording them the chance to demonstrate the personal circumstances based on which they might challenge their return, constitutes a violation of the prohibition on returns set out under Article 3 of the Convention, as well as of the prohibition on collective expulsions established in Article 4 of its fourth additional protocol. ${ }^{0}$

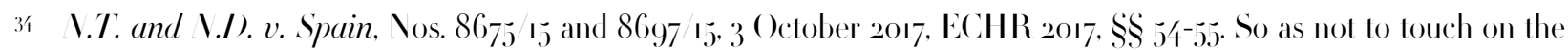
Spanish-Morocean dispute even incidentally, the court based its jurisdiction on the verified effective control by the civil guard officers over the plaintifls in the intermediate zone.

35 For the ECIIIR, the use of automatic and indiscriminate lethal systems in the context of the practice and legislation concerning the Berlin Wall and the categorical nature of the order to "annihilate border violators" were not only a breach of international human rights law but also criminal conduct according to the general principles of law recognized by the international community. Therefore, the authors' punishment could not be considered a violation of the principle of legality in criminal law, even if these practices were required under the domestic law of the GDR. See: Strelelz, Kessler and Krenz $v$.

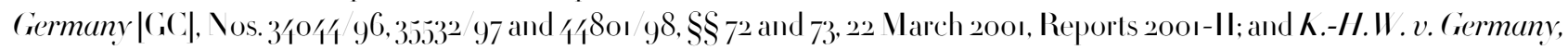
Vo. 37201 97, $\$ \$ 66$ and 67, 22 March 2001, Reports 2001-II. The IIuman Rights Commillee reached a similar conclusion. See: Baumgarlen v. Germany, Communication to $960 / 2000$, Human Rights Commillee (CCPR), $78^{\text {ht }}$ session, Doc.

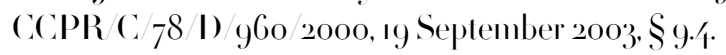

$3^{6}$ Europa Press, 'El Defensor del Pueblo: “Las concerlinas es un sistema de una crueldad extraordinaria”, I/4 June 2018.

37 In the Sale case, the US Supreme Court upheld the policy of offshore interdiction and automatic return ordered by President G.II.W. Bush to address the problem of Ilaitian "boat people" in the early rggos, essentially based on the supposed lack of extraterritorial effectiveness of the non-refoulement principle set out in Art. 33 of the Geneva Convention. Sale $v$. IIailian Centers Council, jog U.S. I.j. (1993), section IV. For a critical analy sis of the case, see: G.S. Goodwin-Gill, The IIaitian Refoulement Case: A Comment', 6 IJIRL (199/), at roz and ff. The solution upheld in the Sale case was rejected four vears later by the Inter-American Commission on IIuman Rights.ComII)II, The IIailian Centre for IIuman Righls el al.v. Uniled Slates, Case $10.675, \$ 157$.

$3^{8}$ In the Tampa case, the Federal Court of Australia upheld the strategy of containing migration at sea known as the "Pacific Solution", holding that the performance of "gatekeeping" functions, i.e. those geared towards preventing entry into Australian territory, were a prerogative power of the executive branch that had not been altered by migration legislation and that the intervention of the Australian agents had not generated a situation of detention that could give rise to the issue of a writ of habeas corpus. Ruddockv. I adarlis |2001| FC I 1329 (18 September 2001), Federal Court (Full Court) (Australia).

39 Ilirsi. Jamaa and olhers v. Italy, 23 February 2012, ECIIIR 2012, \$\$ 81-82.

to Idem, $\$ \$ 122$ and ff., and 180 and If. The extraordinary interest that the IIirsi. Jamaa case elicitedin the literature bears witness to its importance. See, amongst others. J. A. Carrillo Salcedo, Reflexiones a la luz de la Sentencia del Tribunal Europeo de Derechos Itumanos en el caso Ilirsi Jamaa y otros contra Italia (Sentencia de 23 de febrero de 2012). Derechos de los inmigrantes en siluación irregular en España, 32 Teoría y Realidad Constilucional (2013), at 28 and ff.; M.I). Bollo Arocena, Push back, expulsiones colectivas y non refoulement. Agunas reflexiones a propósito de la sentencia dictada por la gran sala del TEI)II en el caso Ilirsi Jamaa y otros c. Italia (2012)', in S. Torres Bernárdez (ed.): El derecho inlernacional en el mundo 


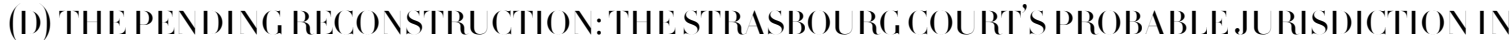
REL ATIONTOOTIIERINTERCEPTION MEISERES

Beyond the aforementioned cases, the question of whether, under the ECIIR, the controls circumvented with the offshoring strategies could be deepened and expanded to include other interception measures is shrouded in incredible uncertainty. Because they are measures implemented abroad, the basis for them must consider the ECIIIR's increasingly broad doctrine in cases in which, in accordance with Article I ECIIR, an individual located beyond a State Party's borders is subject to its jurisdiction. IIowever, because these measures are increasingly implemented by bodies, agenls or individuals that do nol have the slatus of a Slate Parly organ and because they increasingly involve multiple players, it is also essential not to lose sight of the international norms governing the attribution of conducts and responsibility to those States. ${ }^{\prime}$ Vevertheless, it must be recalled that the solutions that these latter norms point to can only be followed to the extent that they are compatible with an instrument that is both a human rights treaty and, in the words of the ECIIIR, the constitutional instrument of European public order. ${ }^{2}$

The concept of extraterritorial regional disembarkation platforms first broached in the summer of 2018 has not yet been sufficiently defined. Ilowever, from the outset it can be said that any formula similar to that tried by the United States in Guantanamo or Australia in Nauru or Papua Vew Guinea would quite likely imply effective control over persons and the exercise of public prerogatives by authorities of the States Parties and would, thus, entail the Convention's application. This may be why the European Commission has clearly distanced itself from such solutions in the still highly ambiguous exploratory exercise it has been conducting regarding that concept. ${ }^{\text {3. }}$

Is for contactless maritime interception operations, 任 i.e. ones that do not include even brief custody of the affected individuals, they must be viewed, first, in relation to those operations verified directly by State Party vessels under the control of the State Party's own agents, who, rather than bringing the intercepted persons on board, simply block the path of their boat, dinghy or other more or less precarious inflatable craft, requiring them to return to the coast of departure or enabling their capture by third-

mullipolar del siglo XV: Obra homenaje al profesor Luis Ignacio Sánchez Rodríguez (Iprolex, Madrid, 2013), at 6/7 and ff.; and V. Moreno-Lax, 'Ilirsi Italy or the Strasbourg Court v Evtraterritorial Migration Control?', IIuman Righls Law Review(2012), at 57 亿 and $1 \mathrm{f}$.

亿 Draft articles on Responsibility of States for Internationally Wrongful Acts, with commentaries (hereinafter, D ARSIII A), Tearbook, of the Inlernational Law Commission (2001), Vol. II (Part Two).

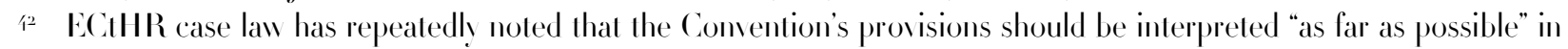

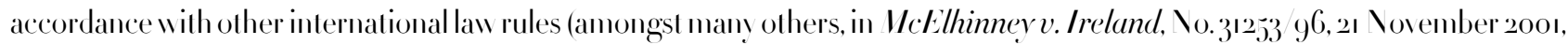

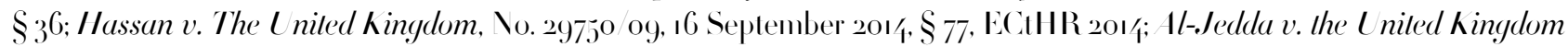

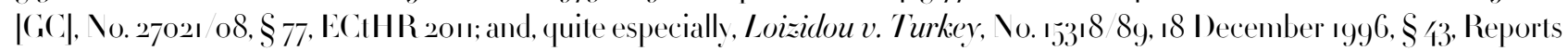

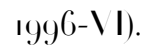

13 European Council, Brussels, 28 June 2018, EU CO 9 18, para.. The idea is still in an exploratory phase: European Commission, Non-paper on regional disembarkation arrangements. Accessible through the hyperlink in the text of the press release Managing migration: Commission expands on disembarkation and controlled centre concepls, Press Release, Brussels, 24.July 2018 .

伯 Terms from V. Moreno Lax and M. Giuffré, "The Rise of Consensual Containment: From "Contactless Control" to "Contactless Responsibility" for Forced Migration Flows', in S. Juss (ed.):Research IIandbook on Inlernational Refugee Law (forthcoming). 
country coastguards. In these situations, the precedents of the Marine It. case before the Commitlee Igainst Torture (CAT) and the Xhavarats case before the ECIIIR make it possible to consider the existence of an effective control over persons that would trigger the Convention's application. Second, building even on the idea of control of specifie situations or events on which essential rights recognized in the Convention depend used by the ECaIIR in the Jaloudis case, surely a basis could be found for the ECIIR's application and the possible responsibility of the States Parties in situations of breach of international search and rescue obligations by State Party vessels present in the area of an accident or whose intervention results in the capture of persons by foreign coastguards. And, third, with regard to joint patrols, such as those conducted by Spanish patrol boats from the Civil Guard's maritime service (SEM AR) in Mauritanian and Senegalese waters, ${ }^{8}$ it could be argued that Spain should be held responsible under the ECIIR. This is because every thing indicates that this is not a case in which it placed its agents or bodies at the disposal of a third state as provided for under Article 6 of the Draft Articles on Responsibility of States for Internationally Wrongful Acts (D ARSIM A), insofar as they are neither under the exclusive direction and control of the third state, nor are they acting pre-eminently for the purposes of that state. ${ }^{\text {? }}$

It could likewise be argued that the Convention, and any responsibility of the States Parties under it, applies in cases in which interception measures are imposed on privale operalors or carried oul through them. In cases similar to that of the incident resulting in the preventive seizure of the Open Arms by the Italian authorities,$^{50}$ and provided the existence of orders or instructions by the relevant state's authorities

4. Committee Igainst Torture, J.II.4. v. Spain, Decision of to December 20o8, Communication No. 323 2007, CAT C/41/ I $3232007, \$ 8.2$.

16. Xhavara and olhers v. Ilaly and Ilbania (Dec.), Jo. 39/37 98, ECallR 2001.

17 .Jaloud v. the Nelherlands, No 47708 o8, 20 November 201/, \$ 139, ECallR 2015. Likewise, in a case involving very similar facts, Pisariv. The Republic of Moldova and Russia, Vo. 22139 12, 2 I April 2015. \$33, ECullR 2015.

is In execution of the Seahorse programmes and Operation Hera, and on board the Civil Guard's SEM AR vessels stationed in Mauritanian and Senegalese ports, the joint patrols carry out surveillance activities against irregular migration and other forms of crime. In that context, under the coordination of the Santa Cruz de Tenerife Coordination Centre, thes participate in interception operations that are even conducted in the territorial sea and contiguous areas of those countries to prevent the departure of cavuco boats and other vessels carrying irregular migrants to the Canary Islands (M. Casas -Cortes, el al., Good Veighbours..., supra n. 1/, at 2/2-2/3; and S. Carrera, The EU Border Management Stralegy: Fronlex and the Challenges of Irregular Immigration in the Canary Islands, CEPS, 2008, at 21-22). There are indications that similar experiences have been attempted by Spain with Moroceo (M.T. Gil-Bazo, The Practice of Mediterranean States in the Context of the European U nion's Justice and I Iome Affairs External Dimension The Safe Third Country Concept Revisited', I8 I.JRL (2006), at 587; and P. García Andrade, Extraterritorial Strategies to Tackle Irregular Immigration by Sea: I Spanish Perspective, in B. Ruan and V. Mitsilegas (eds.):Extralerrilorial..., supra n. 7, at 319) and bs Itals with Libva (M. I)en Ileijer, 'Europe beyond Its Borders: Refugee and I Iuman Rights Protection in Extraterritorial Immigration Control', in B. Ruan and V. Mitsilegas:Extralerrilorial..., supra n. 7, at 172). The opacity that, as noted, surrounds these lypes of actions makes it difficult to determine the exact action protocols and, therefore, to know what would seem to be a decisive piece of information when applying the rules to determine the existence of jurisdiction and/or the attribution of responsibility to the European States, namely, the exact role that the States Parties' agents play in the interception operations.

19 On the interpretation of Art. 6.2 D ARSIII A on which that observation is based, see the corresponding commentary in ILC Yearbook (2001), supra n. 很, at 行.

5o See: A. Sánchez Legido, ¿'Héroes o villanos? Las O \G de rescate y las políticas europeas de lucha contra la inmigración irregular (A propósito del caso Open Arms), , 40 Revisla General de Derecho Europeo (2018). 
could be accredited, any delivery of persons rescued by private vessels, whether belonging to rescue YGOs or otherwise, to foreign authorities - e.g. the Libyan coastguard where there exists a risk of serious violation of essential rights recognized under the Convention could be considered a case of personal control through interposition verified by the private operator acting under those authorities' instruction and control. This would trigger a possible breach of the Convention attributable, for the same reason, to that State Party in accordance with Article 8 D ARSII A.

Similarly, the overseas performance by diplomatic or consular authorities of functions linked, amongst other things, to migration control and access to the territory is a case that the ECIIR implementing bodies have already accepted as triggering its extraterritorial application. ${ }^{5}$ In light of that finding, it can be quite plausibly asserted that the States Parties are responsible under the Convention for actions to control access to means of transport carried out by private carriers overseas. In fact, the IIC itself cited such control activities to exemplify the cases, falling under Article $̧$ D ARSIII A, of attribution to a State of the conduct of entities empowered to exercise its governmental authority when they act in that capacity..$^{2}$

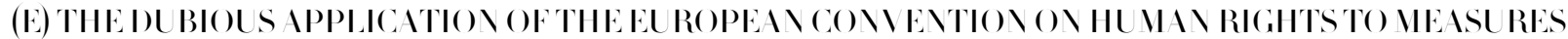

\section{ENCOURIGINGCOOPER UTIONON MIGRUTION CONTROL BI ST ITESOF ORIGIN IVOTRIISIT}

In contrast, the difficulties involved in justifying that the ECIIR and its enforcement body could be, respectively, the appropriate instrument and channel for establishing the legal responsibility of States Parlies for policies aimed at encouraging and/or forcing states of origin and transit to perform strict border controls - in this case, to prevent departures - are almost insurmountable. For one thing, the need to have been personally affected in some way, whether directly or indirectly, ${ }^{33}$ implicit in the

${ }^{5} \quad$ The Strasbourg court considers it "clear" that "the acts of diplomatic and consular agents, who are present in a foreign territory in accordance with provisions of international law, may amount to an exercise of jurisdiction when these agents exert authority and control over others". Al-Skeini and olhers v. The U niled Kingdom, \o 5j721 07, 7 July 2011, \$ 134; and Bankovic and olhers v. Belgium and olhers (Dec.) |GC., No. j2207 99, \$ 75, 12 December 2001, Reports 20o1-XII, $\$ 73$. Based on its reference to the case law of the former European Commission of Ituman Rights in making this assertion, the Court is understood to accept as cases involving the exercise of jurisdiction and consequent application of the Convention actions aimed at promoling the expulsion of an individual from a third state (X. v. Germany, No. I6ı 62, Commission Decision of 25 September ${ }_{9} 6_{5}$, Yearbook 8 , at 158 ), to respond to claims aimed at obtaining the custody of a minor residing in a Member State

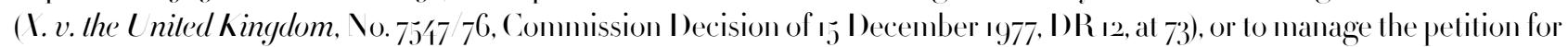
protection before the host state authorities, at least when it is resolved, allowing said authorities to enter diplomatic premises and arrest the interested parties (II. Y. v. Denmark, \o. 17392 9o, Commission Decision of I/4 Oclober 1992, I)R 73, at 193).

$5^{2} \quad$ In what appears to answer the question of whether this is an example of the de facto case provided for in this precept, in its commentaries, the International Law Commission mentions as an example cases in which "Ip|rivate or State-owned airlines may have delegated to them certain powers in relation to immigration control”. I) ARSII A, commentary to Article 5 , para. 2 ,

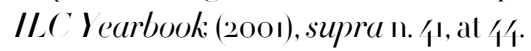

33 According to the doctrine laid down by the Strasbourg court, an individual does not have standing to sue a State Party unless that individual can accredit that he or she is affected by the violation he or she cites from the Convention. If that violation is the result of general policies or measures, that means that, except in exceptional cases - e.g. secret measures that make it impossible to know whether a potential victim has really been affected or not only those people who have been the subject of actions involving the application of those measures have access to the court. Xhavara (2001), supra n. 仵, $\$$ 亿. 
establishment of the status of victim required for individual applications to be admissible (Article 3 亿 ECIIR) makes the possibility of using this procedure to call on the ECIIIR to act against alleged violations arising from general laws or policies extremely unlikely.

Additionally, according to the criteria set out in the D ARSIII A, it is all but impossible to attribute to the States Parties executive interception actions that, whilst encouraged by European states, are carried out in territories outside their sovereignty and not subject to their effective control by third-country bodies that are not acting under their instructions, direction or control. The Draft Articles provide for two cases in which pressure by one state over another could give rise to the former's international responsibility. In both cases, however, the requirements to be met are so strict that their concurrence in the cases considered here is exceedingly unlikely. With regard to the first case direction and control exercised over the commission of an internationally wrongful act by another state provided for under Article r7, the IIC. has insisted that it refers to cases of domination and/or actual direction by one state over the specific conduct performed by another and that it cannot be construed as includingmere influence or concern, nor mere incitement or suggestion. ${ }^{31}$ Meanwhile, for the pressure applied to constitute coercion triggering responsibility for the act carried out by the coerced state - in this case, an interception measure - as provided for under Article I8, the ILC has indicated that it must have the same essential character as force majeure, such that the coereed state has no choice but to commit the wrongful act. In other words, it is not enough for the pressure simply to have made compliance with the obligation in question more difficult or onerous. ${ }^{53}$ These same considerations suggest that, in theory, none of the criteria used by the ECullR as jurisdiction links triggering the Convention's application is met.

However, the assistance provided by the European countries and, especially, Italy to the Libyan coaslguard is of such a singular nature as to raise the question of whether the Libyan agents' actions in the respingimenti per procura, or 'pull-back by proxy', might not give rise to situations in which migrants and refugees would be subject to Italian jurisdiction, which, in turn, would trigger Italy's responsibility under the Convention. Just as the ECIIIR has indicated, in the Jorthern Cyprus, Transnistria and VagornoKarabakh cases, that jurisdiction exists when the entities that effectively control a territory depend on the support and assistance of a State Party for their very existence, ${ }^{-6}$ it can be plausibly understood that this could also be the case when the support and assistance of the State Party is vital to the performance of actions involving effective control over persons, as well as a possible breach of the Convention. Whether the support provided by Italy and other European states to the Libyan coaslguards can be considered vital in this way and whether the resulting personal control can be used as grounds for the Court's jurisdiction and the responsibility of those states under the Convention are questions that the ECAIIR will have to settle

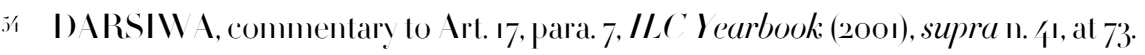

I) IRSIII A, commentary to Art. I8, para. 2, ILC Y earbook (2001), supra n. 4, at 73.

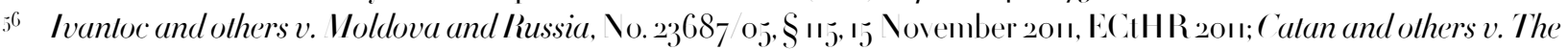
Republic of Moldova and Russia, \o. 13370 o, 19 October 2012,supra, \$ 122; Mozerv. The Republic of Moldova and Russia,

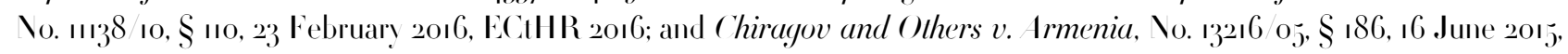
ECIIIR 2015 . 
in response to a lawsuit filed in May 2018 over an incident that took place months earlier involving the Sea"Walch.3, in which more than 20 people drowned.57

Aside from exceptional cases of vital assistance, and even though Article I6 D ARSII A provides for the hypothetical case of responsibility for aid and assistance in the commission of a wrongful act by another state that, in this case, by definition, is not a State Party to the ECIIR, it is virtually impossible to claim that jurisdiction under Article I exists and, thus, that the Court is competent in relation to interception actions performed by third states that maintain the capacity to perform their intrinsic functions - as occurs in the most important cases for Spanish practice. Therefore, and for elementary considerations of democratic conviction, it is absolutely essential to do away with the obscurantism and lack of effective parliamentary oversight that, under cover of secret memoranda of understanding, have characterized Spain's operational cooperation with half a dozen African countries and, especially, Mauritania and Senegal.

\section{(F) PROBLEVS OF RESPO SSIBILITY IND JU DICINLONERSIGIT IRISIXGFRON FRONTEX'S INOLLEVENTIXINTERCEPTION MEISURES}

In a development as necessary as it is positive, the more or less founded suspicions regarding Frontex's involvement in human rights violations ${ }^{-8}$ have given rise to a process to correct, at least, the most glaring structural shortcomings that, from the point of view of respect for fundamental rights, marred the Agency's original configuration, leading it to be regarded as some sort of irresponsible legal monster. Today, its obligations with regard to fundamental rights are much clearer and more specifie, and the institutions created within it to promote and monitor this respect - the Consultative Forum and the Fundamental Rights Officer (FRO) - should be able to effectively ensure it. A suitable functioning of the new individual complaint mechanism would be helpful in that regard. Ilowever, the scant means allocated to the FRO ${ }^{59}$ and, especially, the strong resistance that the Agency continues to show to accepting transparency requirements with all of the ensuing consequences are grounds for serious concern.

Although the current Frontex Regulation clearly lays out the obligation of States participating in operations coordinated by the Agency to respect fundamental rights, ${ }^{60}$ there is still some ambiguity. Its execulive bodies thus have broad discretion with regard to the measures to be taken in response to

57 See: Mare Clausum. The Sea Walch vs Libyan Coasl Guard Case. 6 November 2or7, available at www. forensicarchitecture.org. For an initial assessment of this case, see: A. Pijnenburg, 'From Italian Pushbacks to Libyan Pullbacks: Is Ilirsi 2.0 in the Making in Strasbourg?', 20 European Journal of Migralion and Law (2018), at 396 and ff.

$5^{8} \quad$ S. Casella Colombeau el al., Agence Fronlex: quelles garanties pour les droils de lllomme. Élude sur lagence européenne aux frontières exlérieures en vue de la refonle de son mandal, Les V erts ALE, Vovember 2oro; and S. Kellerel al., Fronlex Agency: II hich Guaranlees for Iluman Righls.', Migreurop, March 2011.

59) I. Arnáez, 'Mecanismos para el control de los derechos fundamentales en las actividades de Frontex', in C. Blasi Casagrán and M. Illamola Dausà (eds.): El control de las agencias del Espacio de Liberlad, Seguridad y Justicia (Madrid, 2016), at 129 .

6o Art. 29:3 Frontex Regulation. 
violations of those rights. ${ }^{6.1}$ Iside from that, it must be recalled that the border guards placed at the disposal of the Agency as provided for under its Regulation are not entities placed al ils disposal in the sense with which this expression is used in the D ARSII A. Therefore, the conduct of these agents is not attributable to it. ${ }^{6.2}$ Hence, in application of the doctrine laid down by the ECIIIR in the Al-Jedda ${ }^{6.3}$ case, given that the assistance and coordination tasks the Agency carries out do not entail effective control or ultimate control and authority over the executive actions carried out by the Member States, their responsibility under the Rome Convention remains intact.

Of course, the possible responsibility of the Member States does not exclude that of the Agency itself. The sort of presumption of non-responsibility that the Agency seems to infer, based on the discourse of its leaders, from the exclusive competence that secondary law grants to Member States over the operational

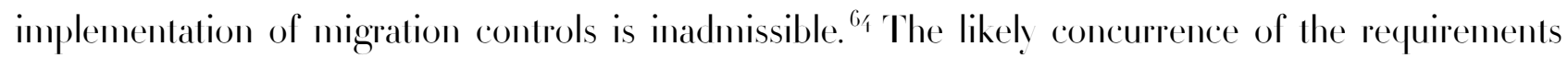
foreseen under the Art. I/ of the Draft Articles on the Responsibility of International Organizations (I) ARIO)could be the basis for the Ageney's legal responsibility, whether complementary or concurrent with that of the Member States, for aiding or assisting in the possible violation of fundamental rights by those states. However, considering that the draft agreement on accession to the ECIIR is at a standstill since Opinion $2 / 2013$, today it is virtually impossible to seek the international responsibility of the Agency, or of the EU, before the ECallR. ${ }^{6.5}$

6r Opinion on the European Ombudsman's own-initiative inquiry into the implementation by Frontex of its fundamental rights obligations, 17 May 2012, at 9 .

6.2 Under the D SRSIII A, placemenlaldisposal involves acting under the authority of the receiving state, i.e. "under its exclusive direction and control, rather than on instructions from the sending State" ${ }^{62}$ Nlthough the concept of placement at disposal is broader under the D ARIO, the attribution of the fact is conditional upon the exercise of effective control over the conduct by the international organization (Art. 7 and, especially, the commentary to para. 8, ILC Yearbook: 2orr, at 62-65). The Frontex Regulation makes it clear that, in the context of operations coordinated by Frontex, the border guards remain under the control of the Member States. See, in particular, Arts. I6.3.f, 21.2, 40.3 and 21.5 of the Frontex Regulation.

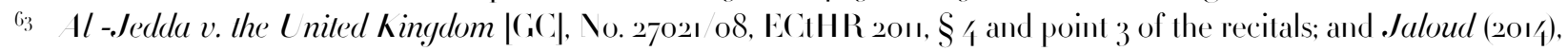
supra n. 17 , $\$ \$ 1 / 9^{-1} 5^{2}$. Without getling into the thorny issue of when there exists "control in the last resort" by an international organization, suffice it to say that it clearly does not seem to exist when, in the words of the Agency's own regulation, the international organization limits itself to "supporting the application of $\mathrm{L}$ nion measures related to exlernal border management through the strengthening, evaluation and coordination of the actions of the Vember States that implement those measures". Preamble, para. 6, and Art. 53 of the Frontex Regulation.

6, Even if it is true that the debate over Frontex's responsibility mav have been driven by a mishandled "blame game" that diverted attention with regard to who the main responsible parties were (J. Rijpma, Frontex: successful blame shifling of the Vember States?', Real Institulo Elcano ( IRI), \o. 69 (2010), at I), it is one thing to acknowledge that reality and quite another to claim that one cannot speak of the Agency's complementary, incidental or residual responsibility in case of violation of obligations linked to respect for fundamental rights that unequivocalls arise for it under the regulation applicable to it.

$6_{5}$ Vevertheless, it must be recalled that the doctrine of equivalent protection by reason of which the Strasbourg court refrains from prosecuting Vember State conduct regulated by EU Law is - as the German Federal Constitutional Court famously put it - solange, i.e., valid provided that or as long as $\mathrm{EU}$ law ensures a level of human rights protection equivalent to that offered, in this case, by the Rome Convention system. It can be deduced from the ILC's work that, were it to be confirmed in any case that Frontex were a simple shield designed or used by the Vember States to evade their obligations and responsibilities under the Convention, those States could incur international responsibility for the Agency's conduct. See Art. 6. IX XRIO ("Circumsention of international obligations of a State member of an international organization"), and the corresponding commentary in which the codifying body invokes the Bosphorus case (Commentary to Art. 6ı, para. f, ILC Yearbook:20II, at no). 
IIowever, certainly since the Treaty of Lisbon, Frontex has unquestionably been subject to the mechanisms for the review of legality and to the actions to establish liability that are the competence of the EC.J. ${ }^{66}$ Notwithstanding the difficulties posed by the strict admissibility and substantive requirements to which the Luxembourg court's action is subject, ${ }^{6} \mathrm{EU}$ law clearly already offers real possibilities to ensure effective judicial review of a legal framework that likewise unequivocally imposes obligations to respect and enforce fundamental rights on all participants in the operations that the Agency coordinates. Nor must it be forgotten that the fact that the EU regulates the Member States' actions in the framework of operations coordinated by the Ageney automatically entails the application - extraterritorial, where necessary of the EU Charter of Fundamental Rights, whose application is not conditional on the existence of the jurisdietional links applicable in the case of the ECIIR. ${ }^{68}$

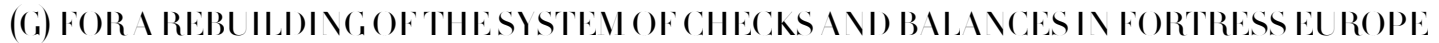

Few areas of action of the European public powers - whether at the Union or national level - pose such a risk of systemic breakdown of the checks and balances of the rule of law as that underlying the policies externalizing migration control. This situation can be dealt with, as has occurred elsewhere, by accepting rigid lines of separation, whether fictitious or manifestly real in the form of walls, based on the idea that only those on the inside are deserving of such enlightened principles. Atternatively, it can be addressed by trying to rebuild the democratic controls to ensure that they accompany migration control wherever it is performed. Possibilities to do so exist, and it is largely in the hands of the European courts to act on them. Whether we wish to see it or not, nothing less than European public order is at stake.

66 On the situation prior to the Lisbon Treaty, see: A. Ilinarejos Parga, Judicial Control in the European Union: Reforming.Jurisdiclion in the Intergovernmenlal Pillars (O)ford, 2009), at 83 and ff.; and V. Mitsilegas, 'Border Security in the European Union: Towards Centralized Controls and Maximum Surveillance, in E. Guild and F. Gyer (eds.):Securily versus Justice." Police and Judicial Cooperalion in the European I nion (Ndershot, 2008), at 374 and ff.

${ }^{6}{ }_{7}$ F. Esteve García, 'El control judicial de las agencias del Espacio de Libertad, Seguridad y Justicia', in C. Blasi Casagrán and M. Illamola Dausà (eds.):El control..., supra n. s9; and, more specifically in relation to Frontex, M. Fink:Fronlex and I/uman Rights: Responsibility in “Multi-1clor Silualions” under the ECIIR and EU Public Liability Law (O\ford, 2018).

68 EC.J, Lkerberg Fransson, EU:C:2013:10б, para. 21; and EC.J, Pfleger and olhers, C-39o I2, EU:C:201/2:28ı, para. 34. 